\title{
Epithelial-to-mesenchymal transition of tumor cells: cancer progression and metastasis
}

\author{
VASILEIOS VARDAS ${ }^{1, \#, ~ E L E N I ~ P O L I T A K I 2, \#, ~ E V A N G E L I A ~ P A N T A Z A K A ~}{ }^{1}$, \\ VASSILIS GEORGOULIAS², GALATEA KALLERGI*,1 \\ ${ }^{1}$ Division of Genetics, Cell and Developmental Biology, Department of Biology, University of Patras, Patras, Greece, \\ ${ }^{2}$ Laboratory of Tumor Cell Biology, School of Medicine, University of Crete, Heraklion, Greece
}

\begin{abstract}
Detection and characterization of circulating tumor cells (CTCs) with an epithelial-tomesenchymal transition (EMT) phenotype is very important, as it can contribute to the identification of high-risk for relapse and death patients. However, most methods underestimate CTC numbers, owing to their dependence on epithelial markers. In the current study, we evaluated the EMT phenotype in CTCs isolated from breast cancer (BC) patients, using the CellSearch system. Spiking experiments for the evaluation of the specificity and sensitivity of our method were performed using HeLa cells. Sixty-five breast cancer (BC) patients (47 early and 18 metastatic) were enrolled in the study. Vimentin is a mesenchymal marker that indicates tumoral cells acquiring invasive and malignant properties. We studied vimentin (VIM) expression using the extra channel of the CellSearch system and an anti-vimentin antibody conjugated with FITC. In our present results, we reported the percentage of circulating tumor cells that expressed vimentin in early and in metastatic breast cancer patients. Interestingly, the incidence of cells with a CK-VIM+CD45- phenotype was detected in both settings. These cells were detected in $31.4 \%$ of CK-negative (11/35) and $82.3 \%$ of CK-positive (10/12) early BC patients. The corresponding numbers for metastatic disease were $15.4 \%(2 / 13)$ and $100 \%(5 / 5)$, respectively. Our results suggest that in CTC-negative patients, potentially undetectable tumor cells could be identified using the FDAapproved CellSearch system, based on the (CK-VIM+CD45-)-phenotype, offering additional information regarding metastatic dissemination in cancer patients. Further experiments evaluating more biomarkers are necessary to elucidate the mechanisms that regulate tumorigenesis and metastasis.
\end{abstract}

KEYWORDS: epithelial-to-mesenchymal transition (EMT), circulating tumor cells (CTCs), breast cancer, vimentin, cytokeratin

\section{Introduction}

Epithelial-to-mesenchymal transition (EMT) and mesenchymalto-epithelial transition (MET) are both critical processes at different stages of early embryonic development. Zinc-finger E-box binding homeobox 1 (ZEB1) is a master regulator of the EMT, regulating the expression of vimentin. These molecules have been implicated in the embryo implantation and in morphogenetic processes during development (Ran et al., 2020). The same physiological mechanism is adopted by cancer cells to migrate, invade, form colonies and proliferate. Tumor cells that leave the primary tumor to enter circulation and finally metastasize are known as circulating tumor cells (CTCs). CTCs have developed ways of surviving in the hostile microenvironment of the bloodstream. More specifically, they can alter their genetic and phenotypic characteristics by expressing specific proteins, and, thus, create beneficial niches, acquire drug resistance, escape immune response and enhance their invasive abilities (Yang et al., 2014). All these genotypic and phenotypic alterations constitute the EMT process and contribute to tumor progression and metastasis (Pantazaka et al., 2021). During EMT, cells pass from their epithelial state to a more mesenchymal

\begin{abstract}
Abbreviations used in this paper: $\mathrm{BC}$, breastcancer; CK, cytokeratin; CTCs, circulating tumor cells; EMT, epithelial-to-mesenchymal transition; EpCAM, epithelial cell adhesion molecule; VIM, vimentin;ZEB1, Zinc-finger E-box binding homeobox 1.
\end{abstract}

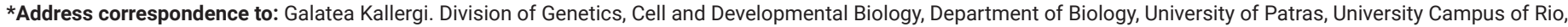
26504, Patras, Greece. Tel: +30-2610-969-248. E-mail: kalergi@med.uoc.gr | https://orcid.org/0000-0001-9825-3871

\#Equal contribution.
}

Submitted: 1 September, 2021; Accepted: 17 October, 2021; Published online: 26 October, 2021. 
phenotype, with maximized invasive abilities, by downregulating epithelial markers such as EpCAM or cytokeratins (CK) and upregulating mesenchymal markers such as vimentin, or the transcription factors Twist and Snail (Pantazaka et al., 2021). A previous study, reporting the existence of CTCs with a higher expression of Twist and vimentin in metastatic $\mathrm{BC}$ compared with early $\mathrm{BC}$, has clearly shown the involvement of EMT in metastasis (Kallergi et al., 2011). Furthermore, increased expression level of Twist has been demonstrated to lead to high vascular endothelial growth factor (VEGF) gene expression, while Twist expression itself is regulated by hypoxia-inducible factor $1 \mathrm{a}(\mathrm{HIF}-1 \mathrm{a})$. Expression of both VEGF and HIF-1a has also been indicated in CTCs of metastatic BC patients (Kallergi et al. 2008, 2009). During EMT, some CTCs maintain a hybrid epithelial/mesenchymal phenotype that provides them with cell junction characteristics, better motility, and maximized aggressiveness (Kallergi et al. 2011, 2018).

Among the CTCs present in the bloodstream are CTCs with stem-cell properties, known as Cancer Stem Cells (CSCs) (Pantazaka et al., 2021). Recent studies suggest that CTCs can be transformed into CSCs through EMT, and hence survive in the bloodstream, subsequently leading to clinical relapse (Mitra et al., 2015). Transcription factors such as NRF2 and OCT4 constitute some of the markers involved in the creation of a stem phenotype in CTCs (Li et al. 2017; Bocci et al. 2019). Furthermore, it has been reported that there is an association between the CD44+/CD24-/ low and aldehyde dehydrogenase $1(\mathrm{ALDH} 1)+$ phenotypes with stemness and increased tumorigenic ability in metastatic BC patients (Theodoropoulos et al., 2010). Expression of high levels of ALDH1 and nuclear Twist has been more frequently observed in CTCs from metastatic BC patients, suggesting that cells with such phenotype survive and prevail during disease progression (Papadaki et al., 2014).

In recent years, liquid biopsy has brought a breakthrough in understanding the mechanisms underlying the metastatic process, as it has improved the acquisition of valuable information originating from the primary tumor with additional real-time data from peripheral blood, instead of conducting invasive methods for the diagnosis of solid cancers (Siravegna et al., 2017). One of the principal applications of liquid biopsy is the enumeration of CTCs, which determines prognosis as well as response to treatment (Mansilla et al., 2018). Numerous studies have been conducted, highlighting the importance of CTC enumeration as a useful tool to evaluate the efficacy of treatment and potentially as a stratification factor of patients in clinical trials (Kalykaki et al. 2008; Agelaki et al. 2015; Cristofanilli et al. 2016). However, the technical aspects for the isolation and characterization of CTCs remain challenging. Several different methods exist for the detection, quantification, enrichment, and characterization of CTCs (Mansilla et al., 2018). Some are dependent on physical traits, such as microfiltration (based on size), microfluidics (deformability and size), density gradient (density), while others are dependent on their phenotypic characteristics, such as immunoaffinity (CellSearch system, magnetic cell isolation, flow cytometry sorting) (Mansilla et al., 2018). Among these, CellSearch is a semi-automated and highly reproducible platform for the enumeration of CTCs (Cristofanilli et al., 2005), which although FDA-approved, is not without limitations. The main limitation of CellSearch is that it uses the epithelial cell adhesion molecule (EpCAM), a surface protein expressed on epithelial cells, as the marker for immunoselection and subsequent
TABLE 1

\section{RECOVERY RATE (\%) OF HELA CELLS BASED ON CYTOKERATIN (CK) EXPRESSION USING THE CELLSEARCH SYSTEM}

\begin{tabular}{cc} 
HeLa cells spiked in $\mathbf{7 . 5} \mathbf{~ m l}$ blood & Recovery (\%) \\
\hline 0 & 0 \\
10 & $65 \pm 7.1$ \\
20 & $39 \pm 12.8$ \\
100 & $41 \pm 4.2$ \\
AVERAGE & $48.3 \pm 8$ \\
\hline
\end{tabular}

CK for quantification of CTCs. However, CTCs reveal heterogeneity and do not have a specific phenotype, which implies that CTCs with different phenotypes cannot be captured by this platform. In addition, epithelial markers, such as EpCAM, are downregulated during EMT, and CTCs harboring such markers could therefore be lost during detection, leading to underestimation of CTC numbers by most current methods (Mansilla et al., 2018).

In general, isolation and further characterization of CTCs based on the expression of specific biomarkers, and understanding the processes that lead to metastasis and tumor progression, are vital. They will contribute to early identification of patients at risk of developing metastasis and will thus permit a more personalized therapeutic approach and an improvement of clinical outcome. The current study aimed to evaluate the EMT phenotype on CTCs isolated from BC patients using the CellSearch system.

\section{Results}

\section{Recovery rate of tumor cells expressing CK using CellSearch}

Spiking experiments were performed using the HeLa (human cervical adenocarcinoma) cell line (Table 1). HeLa cells were used for the evaluation of vimentin expression, since they have been proposed as positive control by the antibody's manufacturers. Furthermore, this cell line had been used as a positive control in our previous study regarding EMT in CTCs (Kallergi et al., 2011).

In the first set of spiking experiments $(n=3)$, we evaluated the recovery rate of HeLa cells using the CellSearch system without the addition of an extra vimentin antibody, thus avoiding potential

TABLE 2

RECOVERY RATE (\%) OF HELA CELLS BASED ON VIMENTIN (VIM) EXPRESSION IN DIFFERENT DILUTIONS AND INTEGRATION TIMES USING THE CELLSEARCH SYSTEM

\begin{tabular}{|c|c|c|c|c|c|}
\hline $\begin{array}{c}\text { HeLa cells } / 7.5 \mathrm{ml} \\
\text { blood of normal } \\
\text { donor }\end{array}$ & $\begin{array}{l}\text { Integration } \\
\text { time }\end{array}$ & $\mathrm{CK}+\mathrm{VIM}+$ & CK+VIM- & $\begin{array}{c}\text { CK+ } \\
\text { recovery (\%) }\end{array}$ & $\begin{array}{c}\text { VIM+ } \\
\text { recovery (\%) }\end{array}$ \\
\hline 0 & 0.2 & 0 & 0 & & \\
\hline 0 & 0.3 & 0 & 0 & & \\
\hline 0 & 0.8 & 0 & 0 & & \\
\hline 10 & 0.2 & 6 & 1 & 70 & 60 \\
\hline 10 & 0.3 & 5 & 1 & 60 & 50 \\
\hline 10 & 0.8 & 6 & 0 & 60 & 60 \\
\hline 100 & 0.2 & 41 & 3 & 44 & 41 \\
\hline 100 & 0.3 & 38 & 0 & 38 & 38 \\
\hline 100 & 0.8 & 40 & 1 & 41 & 40 \\
\hline $\begin{array}{c}50 \text { (without vimentin } \\
\text { antibody) }\end{array}$ & 0.2 & 0 & 24 & 48 & 0 \\
\hline $\begin{array}{l}50 \text { (without vimentin } \\
\text { antibody) }\end{array}$ & 0.8 & 0 & 15 & 30 & 0 \\
\hline
\end{tabular}


TABLE 3

\section{AVERAGE RECOVERY RATE (\%) OF CYTOKERATIN+ (CK+) AND VIMENTIN+ IN HELA CELLS}

\begin{tabular}{ccc}
$\begin{array}{c}\text { HeLa cells/7.5 ml } \\
\text { blood of normal donor }\end{array}$ & Average Recovery CK+ (\%) & Average Recovery vimentin (\%) \\
\hline 0 & $0 \pm 0$ & $0 \pm 0$ \\
10 & $63.3 \pm 5.8$ & $57 \pm 5.8$ \\
100 & $41 \pm 3$ & $39.7 \pm 1.53$ \\
\hline
\end{tabular}

cross-talk with the vimentin antibody (Table 1 ). The mean recovery rate in the dilution of 10 tumor cells $/ 7.5 \mathrm{ml}$ was $65 \% \pm 7.1$, in the dilution of 20 cells $/ 7.5 \mathrm{ml}$ it was $39 \% \pm 12.8$, and in that of 100 cells $/ 7.5 \mathrm{ml}$ it was $41 \% \pm 4.24$. No cells were observed in normal blood samples without HeLa cells. The average recovery rate of tumor cells spiked into $7.5 \mathrm{ml}$ of normal blood at the 4 different cell dilutions $(0,10,20$, and 100 cells $/ 7.5 \mathrm{ml})$ was $48.3 \% \pm 8$.

Recovery rate of HeLa cells expressing vimentin with CellSearch

In the next set of experiments, the fourth channel of the CellSearch system was used to identify vimentin- positive CTCs. Since the vimentin antibody was not included in the common CellSearch kit, we performed spiking experiments to evaluate the specificity and sensitivity of this antibody. Consequently, we used these experiments as positive and negative controls for analysis of patient samples. The recovery rate of HeLa cells spiked into 7.5 $\mathrm{ml}$ of normal blood that expressed vimentin and were assessed by CellSearch is shown in Table 2. We tested different integration times $(0.2,0.3$, and 0.8$)$ in every dilution of HeLa cells. The best recovery rate was identified at the integration time of 0.2 in all the dilutions. The mean recovery rate based on CK expression in HeLa cells was $63.3 \% \pm 5.8$ and $41 \% \pm 3$ for 10 and 100 spiked cells $/ 7.5 \mathrm{ml}$ of blood, while recovery based on vimentin was $57 \%$ \pm 5.8 and $39.7 \% \pm 1.53$, respectively (Table 3 ), indicating that there were some HeLa cells with undetectable expression of vimentin, which were characterized as vimentin-negative. No expression of vimentin-positive HeLa cells could be identified in control experiments in the absence of anti- vimentin antibody.

Finally, the recovery rate in this second set of experiments was not statistically different in any dilutions from the first set without the vimentin antibody, irrespective of the dilution used, indicating that the addition of an extra antibody does not change the recovery rate of the CellSearch system.

\section{Vimentin expression in early $B C$ patients}

Forty-seven early BC patients were enrolled in this study and were analyzed for both CK and vimentin expression. Twelve patients $(25.5 \%)$ were characterized as CTC-positive based on the CK expression. These patients harbored cells with a CK+CD45-Dapi+ phenotype (Fig. 1).

Further analysis of the vimentin channel revealed that only $3(25 \%)$ of the CTC-positive patients had vimentin expression (CK+CD45-VIM+Dapi+ phenotype) in their CTCs (Fig. 2). Among the total number of patients (47), only $6.25 \%$ expressed vimentin in their CTCs.

Fig. 1 shows the three different subgroups of cells obtained by the

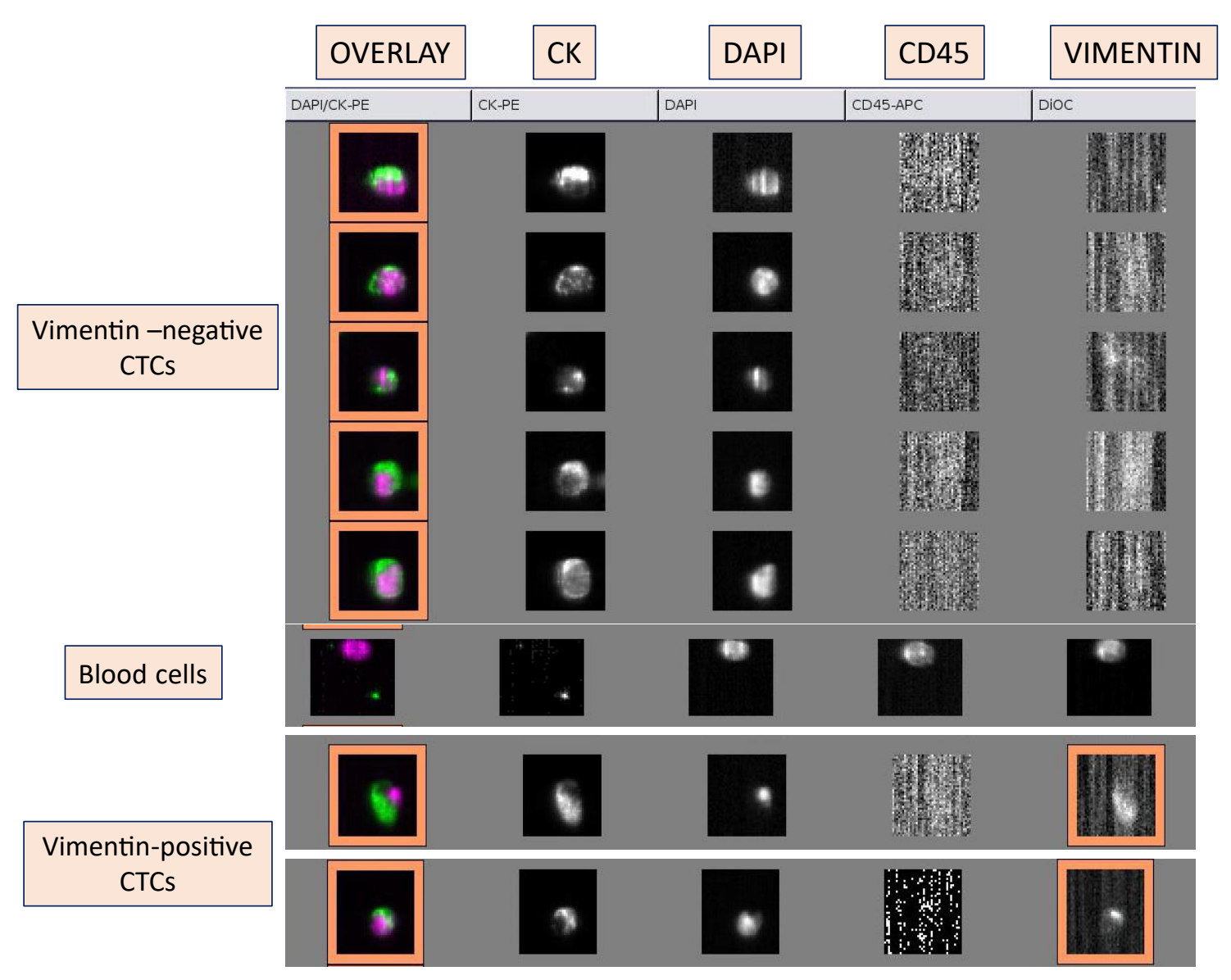

Fig. 1. Gallery of images obtained from CellSearch system. Circulating tumor cells (CTCS) were detected using the CellSearch system and characterised as vimentin-negative [upper panel; CTCs stained for Dapi, expressing Cytokeratin (CK) but not CD45 or vimentin] and vimentin-positive (lower panel; CTCs expressing both CKand vimentin). Themiddle panel presents a typical set of images for hematopoietic cells; cells stained for Dapi, negative for $\mathrm{CK}$, but positive for CD45. 
A

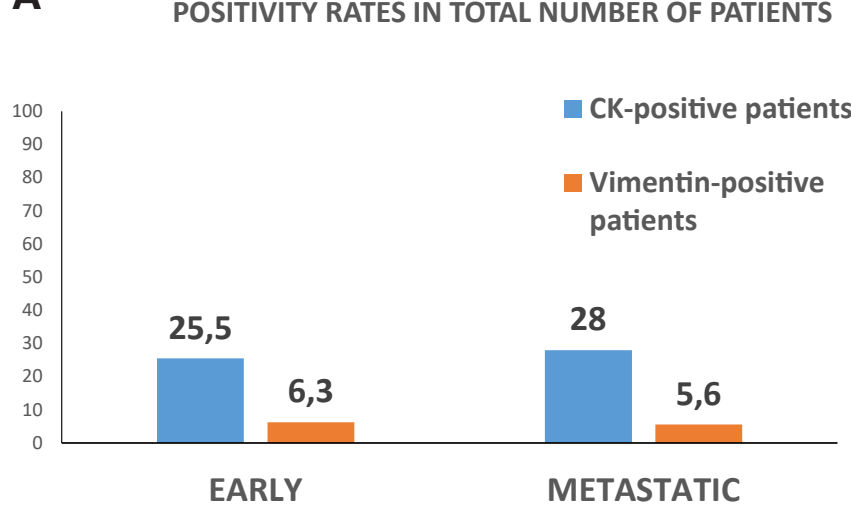

B

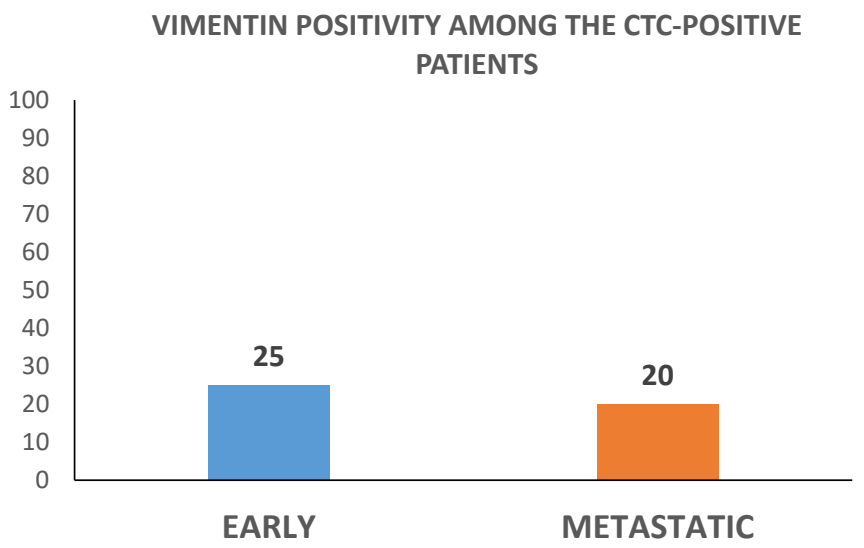

Fig. 2. Detection of vimentin expression using CellSearch system. (A) Percentage of Cytokeratin (CK)-positive and vimentin-positive BC patients among the total number of patients in early and metastatic setting. (B) Percentage of vimentin-positive CTCs detected among the CTC-positive patients in early and metastatic.

CellSearch system. The first group presents tumor cells stained for CK and Dapi without CD45 expression, a hematopoietic biomarker. The second type of cell is a hematopoietic cell; negative for CK and positive for CD45 and Dapi. Finally, the third group includes tumor cells with both $\mathrm{CK}$ and vimentin expression.

Interestingly, analysis of the rest of the captured cells revealed that there were many CK- negative/vimentin-positive/CD45negative cells (CK-VIM+CD45-Dapi+) in the samples of early BC patients. Many of these cells could be "hidden" CTCs, since they do not express epithelial (CK) or hematopoietic (CD45) antigens. Particularly, analysis of the CTC-negative group $(n=35)$ of early BC patients showed that 11 patients $(31.40 \%)$ harbored cells bearing the (CK-VIM+CD45-Dapi+) phenotype in their blood. Furthermore, among the CTC-positive group ( $n=12$ patients), this phenotype was detected in 10 (83.30\%) of them (Fig. 3A).

Fig. 3B shows cells obtained by CellSearch with potential malignant phenotype; negative for epithelial markers such a CK, negative for hematopoietic markers such as CD45, but positive for Dapi and vimentin.

\section{Vimentin expression in metastatic BC patients}

Vimentin and CK expression was evaluated in 18 metastatic $\mathrm{BC}$ patients using the CellSearch system. Five of them (28\%) had detectable CTCs bearing the (CK+CD45-Dapi+) phenotype.

Vimentin analysis revealed that 1 out of 5 CTC-positive patients (20\%) showed vimentin expression, thus displaying the (CK+VIM+CD45-Dapi+) phenotype (Fig. 2B). Among the total number of patients, the corresponding percentage was $5.60 \%$ $(1 / 18)$ (Fig. 2A).

Analysis of the isolated cells revealed that the (CK-VIM+CD45Dapi+) phenotype was also present in the metastatic patients. Specifically, in the CTC-negative ( $n=13$ patients) group, two patients harbored CTCs with this phenotype, while in the CTC-positive group ( $n=5$ patients), all (100\%) had CTCs with (CK- VIM+CD45-Dapi+) phenotype (Fig. 3A).

\section{Discussion}

Detection and characterization of CTCs is a promising and valuable tool for cancer diagnosis and treatment efficacy in BC.
It is now widely accepted that during EMT, tumor cells lose their epithelial characteristics and acquire a mesenchymal phenotype that can render them increasingly invasive (Pantazaka et al., 2021). Epithelial markers such as EpCAM and E-cadherin are downregulated during this process, and mesenchymal markers such as $\mathrm{N}$-cadherin or vimentin are upregulated (Pantazaka et al., 2021). The CellSearch system, which was evaluated in this study, has been developed for enumeration of CTCs of epithelial origin, and more specifically is based on the EpCAM marker and CK assessment (Riethdorf et al. 2007; Kallergi et al. 2016; Swennenhuis et al. 2016). This means that CTCs with a mesenchymal phenotype, i.e. CTCs expressing vimentin, might be "lost" and not captured by the CellSearch system. Detection of CTCs with EMT phenotypes is crucial; a high incidence of these cells is observed in patients with metastatic disease compared with early-stage patients, indicating the likely involvement of EMT in metastasis (Kallergi et al., 2011). We have previously reported a significantly lower recovery rate, using the CellSearch system, for the BC cell line MDA-MB 231 (40.60\%) compared with MCF7 (66.60\%), suggesting that some tumor cells escaped detection, and attributing this loss to the EMT phenotype of MDA-MB 231 cells (Kallergi et al., 2016). CTCs with phenotypes, such as $\mathrm{CK}+/ \mathrm{Ki} 67+$ and $\mathrm{CK}+/$ Vim+, could be detected in several small cell lung cancer patients with undetectable CTCs by the CellSearch, while additional immunofluorescence experiments in the same patients showed that the phenotypes $\mathrm{CK}+/$ EpCAM+or VIM+'EpCAM+ were not detected, clearly implying the failure of CellSearch to capture CTCs with EMT phenotypes (Messaritakis et al., 2017).

In the current study, we examined the EMT phenotype of CTCs isolated from early and metastatic BC patients by using the CellSearch system. CTCs (CK+CD45-Dapi+) were found in $25.5 \%$ and $28 \%$ of early and metastatic patients. Since this positivity rate is rather low compared with other detection methods (Kallergi et al. 2016, 2018), we decided to assess whether these patients harbor CTCs bearing a mesenchymal phenotype, by using an antivimentin antibody in the extra channel of the CellSearch system. The specificity and sensitivity of our staining were addressed by spiking experiments of HeLa cells in healthy donors' blood. Our study revealed that CellSearch could identify CTCs with vimentin expression. However, the detection rate was lower (25\% and 20\% 
A

Incidence of CK-VIM+CD45- cells

\section{CTC-positive patients}

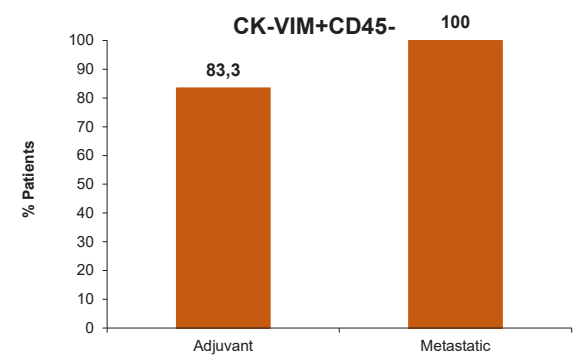

B

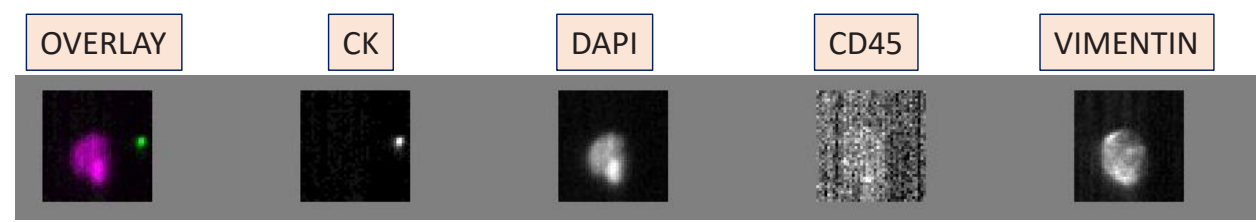

Fig. 3. Incidence of CK-VIM+CD45- cells. (A) Percentage of Cytokeratin (CK)-negative/vimentin-positive/ CD45-negative cells in CTC-positive and negative early and metastatic patients. (B) Representative panel of images of CK-negative CTCs expressing vimentin using the CellSearch system.

for early and metastatic CTC-positive patients, respectively) compared with other methods such as immunofluorescence staining after Ficoll-Hypaque isolation of CTCs (Kallergi et al., 2011). In that study, vimentin-positive CTCs were detected in $100 \%$ and $77 \%$ of patients with metastatic and early-stage disease, respectively. A later study using immunofluorescence staining has shown high percentage of early BC (54.5\%) and metastatic (62.5\%) patients with a (GLU+VIM+CK+) phenotype (Kallergi et al., 2018). Cellsurface vimentin (CSV) is another method that has been observed to generate higher CTC detection rates (all over $60 \%$ ) in most solid tumors compared with EpCAM isolation (Gao et al., 2021). Additional findings from a comparison between CellSearch and CSV method in prostate cancer patients showed greater sensitivity and specificity, as well as a higher number of CTCs by CSV-based method compared to CellSearch (Satelli et al., 2017).

Detection of CTCs and vimentin expression can also be evaluated by cell size selection systems, such as the ISET system. ISET is a non-EpCAM dependent method, and identification of a higher number of CTCs in the peripheral blood than via CellSearch has been indicated (Tamminga et al., 2020). The fact that the ISET methodology is based on morphological analysis and is antigenindependent leads to a more accurate and targeted characterization of EMT (Ma et al., 2013). Comparison between CellSearch and the ISET system has shown a significantly higher recovery rate of CTCs (more than 90\%) using the latter (Kallergi et al., 2016). Furthermore, positive and negative selection of MCF7 using Dynal beads showed an average recovery rate of $75 \%$ for positive selection and $97 \%$ for negative selection (Kallergi et al., 2016). Finally, a comparison between CellSieve, which is based on microfiltration, and CellSearch, showed higher capture of CK+CD45- cells (979) from 21 BC patients using CellSieve than using the CellSearch system (162), demonstrating the greater efficiency of non- EpCAM-dependent techniques in the detection of CTCs (Adams et al., 2015). All these are explained by the fact that CellSearch selects only EpCAM-positive CTCs, excluding CTCs with mesenchymal phenotypes (Riethdorf et al., 2007). It has also been suggested that CTCs with an "intermediate phenotype", such as CK+VIM+, might possess the highest capability of adapting to the conditions present in secondary sites (Tam and Weinberg, 2013). This case is supported by the findings of a study demonstrating strong expression of EpCAM as well as CK concurrently with the expression of SNAIL, ALDH1, and CD133 in patients with colon cancer (Cayrefourcq et al., 2015). In addition to this, it has been stated that simultaneous expression of VIM and CK in BC cells appears to be associated with reduced survival rates in $\mathrm{BC}$ patients, implying the importance of detection and characterization of CTCs with these phenotypes (Shioiri et al., 2006).

To address the above considerations regarding the EMT phenotype of CTCs isolated by the CellSearch system, we evaluated all the different types of isolated cells from both early and metastatic patients, despite CK expression. Interestingly, we detected cells with (CK-CD45-VIM+Dapi+) phenotype in both early and metastatic patients. Specifically, $83.3 \%$ and $100 \%$ of the CTC-positive patients harbored these cells, respectively. However, the most remarkable observation was that patients characterized as CTC-negative had also detectable (CK-VIM+CD45-Dapi+) cells in both settings (31.4\% early and $15.4 \%$ metastatic), implying that many patients characterized as CTC-negative based only on the expression of epithelial markers might harbor undetectable tumor cells in their blood. Extra biomarkers could confirm this notion; however, the CellSearch system does not comprise more free channels for additional antibodies. These data are supported by another study, which used CELLection ${ }^{\mathrm{TM}}$ Dynabeads coated with the monoclonal antibody against EpCAM, to isolate CTCs (Raimondi et al., 2011). According to that study, $34 \%$ of $\mathrm{BC}$ patients were found to possess cells with negative CK/CD45 expression, but a positive expression of the EMT markers vimentin and fibronectin. Attempts to select these cells by CK immunostaining may not be successful due to downregulation of CKs (Raimondi et al., 2011). Another interesting finding of that study was that the absence of CK8, CK18, and CK19 expression was associated with up-regulation of vimentin, suggesting that these CTCs had changed into a mesenchymal phenotype, making them more aggressive. Additional support for our findings is provided by another study where $27 \%$ of CK-negative samples were found to be positive for vimentin and $24 \%$ for slug, with slug and vimentin co-expressed in the majority of these CK-negative CTCs (Serrano et al., 2014). 
All these data indicate that CTCs are not fully characterized yet and that methods like CellSearch have limited efficacy in the detection of these cells. The observed (CK-CD45-VIM+Dapi+) phenotype in the current study could potentially preclude tumor cells characterized by complete loss of epithelial antigens. Therefore, further studies using additional EMT biomarkers are necessary to fully characterize the epithelial and EMT status of CTCs during the different clinical phases and correlate them with response to treatment and patients' clinical outcome.

\section{Materials and Methods}

\section{Cell culture}

HeLa cells (obtained from ATCC) were used for control experiments. HeLa cells were cultured in 1:1 Dulbecco's modified Eagle medium supplemented with $10 \%$ FBS and $50 \mathrm{mg} / \mathrm{ml}$ penicillin/ streptomycin. Cells were maintained in a humidified atmosphere of $5 \%$ CO2-95\% air. Sub-cultivation was performed with $0.25 \%$ trypsin and $5 \mathrm{mM}$ EDTA (GIBCO-BRL). All experiments were performed during the logarithmic growth phase.

\section{Preparation of healthy donors' blood samples for spiking experi- ments}

Peripheral blood $(7.5 \mathrm{ml})$ obtained from 10 healthy blood donors was kept at RT in CellSave preservative tubes (Immunicon Inc, Huntingdon Valley, PA, USA), and processed within 72 hours after blood draw. Serial dilutions of HeLa cells $(0,10,20$, and 100 cells $/ 7.5 \mathrm{ml}$ of blood) were performed.

\section{CTC enrichment and detection by CellSearch}

Sixty-five patients were enrolled in the current study. Forty-seven patients had early-stage disease and 18 metastatic disease. The detection of CTCs was performed before the initiation of any adjuvant treatment (within 20-45 days after the excision of the primary tumor) in the group of early-stage $\mathrm{BC}$ patients and before the initiation of first line chemotherapy in the group of metastatic $\mathrm{BC}$ patients. This study was approved by the ethics and scientific committees of our institution, and all patients and healthy blood donors gave their informed consent to participate in the study.

The CellSearch System (Immunicon) was used for the isolation and enumeration of CTCs in peripheral blood. CellSearch is the only FDA approved system for the detection and enumeration of Circulating Tumor Cells isolated from the blood stream of metastatic breast, prostate, and colon cancer patients. It selects tumor cells based on epithelial markers, while it also uses the CD45 antibody to exclude hematopoietic cells. Specifically, CellSearch belongs to the label-dependent technologies of liquid biopsy, whereby EpCAM+ cells are selected by EpCAM-coated ferrofluid nanoparticles. Enriched cells are subsequently verified by IF for CK $8,18,19$ and the absence of CD45. $22.5 \mathrm{ml}(3 \times 7.5 \mathrm{ml})$ of blood was collected from the patients with early-stage $B C$ in CellSave preservative tubes (Immunicon Inc, Huntingdon Valley, PA, USA). From metastatic patients, $7.5 \mathrm{ml}$ of blood was collected according to previous publications (Cristofanilli et al., 2004). The samples were placed on the Cell Tracks Autoprep System. The CellSearch Circulating Tumor Cell Kit was used (Veridex Warren, NJ.) containing ferrofluid particles coated with EpCAM antibodies, phycoerythrinconjugated CK antibodies and allophycocyanin-conjugated CD45 antibody. Vimentin in CTCs was stained with vimentin-FITC con- jugated antibody (Biodesign, International, US). In the final step, the selected cells were transferred automatically into a cartridge in MagNest placed in Cell Tracks Analyzer II. Cell Tracks Analyzer II is equipped with a semi- automated fluorescent microscope (4 fluorescent filter cubes), covering the entire surface of the cartridge, which captures images of the immunomagnetically selected and fluorescently labeled cells.

Image presentation took place in a gallery format following the predetermined criteria (specified by Veridex) for CTCs, including round to oval morphology, visible nucleus within the cytoplasm, positive CK- phycoerythrin, positive Dapi, negative CD45-allophycocyanin, and minimum size of $4 \mu \mathrm{m}$.

\section{Acknowledgements}

This research has been co-financed by the European Regional Development Fund of the European Union and Greek funds through the Operational Program Competitiveness Entrepreneurship and Innovation, under the call RESEARCH-CREATE-INNOVATE (project code:T1EDK-01562). It was also supported by Grant (project code: 81351) from the Research Committee of the University of Patras via "C. CARATHEODORI" program.

\section{References}

ADAMS D. L., STEFANSSON S., HAUDENSCHILD C., MARTIN S. S., CHARPENTIER M., CHUMSRI S., CRISTOFANILLI M., TANG C.M., ALPAUGH R. K. (2015). Cytometric characterization of Circulating Tumor Cells Captured by microfiltration and their correlation to the cellsearch ${ }^{\circledR}$ CTC test . Cytometry Part A 87: 137-144 https://doi.org/10.1002/cyto.a.22613

AGELAKI S., KALYKAKI A., MARKOMANOLAKI H., PAPADAKI M. A., KALLERGI G., HATZIDAKI D., KALBAKIS K., MAVROUDIS D., GEORGOULIAS V. (2015). Efficacy of Lapatinib in Therapy-Resistant HER2-Positive Circulating Tumor Cells in Metastatic Breast Cancer. PLOS ONE 10: e0123683. https://doi.org/10.1371/ journal.pone. 0123683

BOCCI F., TRIPATHI S. C., VILCHEZ MERCEDES S. A., GEORGE J. T., CASABAR J. P., WONG P. K., HANASH S. M., LEVINE H., ONUCHIC J. N., JOLLY M. K. (2019) NRF2 activates a partial epithelial-mesenchymal transition and is maximally present in a hybrid epithelial/mesenchymal phenotype. Integrative Biology 11: 251-263. https://doi.org/10.1093/intbio/zyz021

CAYREFOURCQ L., MAZARD T., JOOSSE S., SOLASSOL J., RAMOS J., ASSENAT E. SCHUMACHERU., COSTES V., MAUDELONDET., PANTEL K., ALIX-PANABIÈRES C. (2015). Establishment and Characterization of a Cell Line from Human Circulating Colon Cancer Cells. Cancer Research 75: 892-901. https://doi.org/10.1158/0008 5472.CAN-14-2613

CRISTOFANILLI M., BUDD G. T., ELLIS M. J., STOPECK A., MATERA J., MILLER M. C., REUBEN J. M., DOYLE G. V., ALLARD W. J., TERSTAPPEN L. W.M.M. HAYES D. F. (2004). Circulating Tumor Cells, Disease Progression, and Survival in Metastatic Breast Cancer. New England Journal of Medicine 351: 781-791. https://doi.org/10.1056/NEJMoa040766

CRISTOFANILLI M., HAYES D. F., BUDD G. T., ELLIS M. J., STOPECK A., REUBEN J. M., DOYLE G. V., MATERA J., ALLARD W. J., MILLER M. C., FRITSCHE H. A., HORTOBAGYI G. N., TERSTAPPEN L. W.M.M. (2005). Circulating Tumor Cells: A Novel Prognostic Factor for Newly Diagnosed Metastatic Breast Cancer. Journal of Clinical Oncology 23: 1420-1430. https://doi.org/10.1200/JC0.2005.08.140

CRISTOFANILLI M., TURNER N. C., BONDARENKO I., RO J., IM S.A., MASUDA N., COLLEONI M., DEMICHELE A., LOI S., VERMA S., IWATA H., HARBECK N., ZHANG K., THEALL K. P., JIANG Y., BARTLETT C. H., KOEHLER M., SLAMON D. (2016). Fulvestrant plus palbociclib versus fulvestrant plus placebo for treatment of hormone-receptor-positive, HER2-negative metastatic breast cancer that progressed on previous endocrine therapy (PALOMA-3): final analysis of the multicentre, double-blind, phase 3 randomised controlled trial. The Lancet Oncology 17: 425-439. https://doi.org/10.1016/S1470-2045(15)00613-0

GAO Y., FAN W.H., SONG Z., LOU H., KANG X. (2021). Comparison of circulating tumor cell (CTC) detection rates with epithelial cell adhesion molecule (EpCAM) and cell surface vimentin (CSV) antibodies in different solid tumors: a retrospective study. PeerJ 9: e10777. https://doi.org/10.7717/peerj.10777 
KALLERGI G., AGELAKI S., KALYKAKI A., STOURNARAS C., MAVROUDIS D., GEORGOULIAS V. (2008). Phosphorylated EGFR and PI3K/Akt signaling kinases are expressed in circulating tumor cells of breast cancer patients. Breast Cancer Research 10: R80. https://doi.org/10.1186/bcr2149

KALLERGI G., MARKOMANOLAKI H., GIANNOUKARAKIV., PAPADAKI M. A., STRATI A., LIANIDOU E. S., GEORGOULIAS V., MAVROUDIS D., AGELAKI S. (2009). Hypoxia-inducible factor-1a and vascular endothelial growth factor expression in circulating tumor cells of breast cancer patients. Breast Cancer Research 11: R84. https://doi.org/10.1186/bcr2452

KALLERGI G., PAPADAKI M. A., POLITAKI E., MAVROUDIS D., GEORGOULIAS V., AGELAKI S. (2011). Epithelial to mesenchymal transition markers expressed in circulating tumour cells of early and metastatic breast cancer patients. Breast Cancer Research 13: R59. https://doi.org/10.1186/bcr2896

KALLERGI G., POLITAKI E., ALKAHTANI S., STOURNARAS C., GEORGOULIAS V. (2016). Evaluation of Isolation Methods for Circulating Tumor Cells (CTCs). Cellular Physiology and Biochemistry 40: 411-419. https://doi.org/10.1159/000452556

KALLERGI G., AGGOURAKI D., ZACHAROPOULOU N., STOURNARASC., GEORGOULIAS V., MARTIN S. S. (2018). Evaluation of a-tubulin, detyrosinated a-tubulin, and vimentin in CTCs: identification of the interaction between CTCs and blood cells through cytoskeletal elements. Breast Cancer Research 20: 67. https://doi. org/10.1186/s13058-018-0993-z

KALYKAKI A, PAPAKOTOULAS P, TSOUSIS S, BOUKOVINAS I, KALBAKIS K, VAMVAKAS L, KOTSAKIS A, VARDAKIS N, PAPADOPOULOU P, GEORGOULIAS V, MAVROUDIS D (2008). Gemcitabine plus oxaliplatin (GEMOX) in pretreated patients with advanced ovarian cancer: a multicenter phase II study of the Hellenic Oncology Research Group (HORG). Anticancer Res 28: 495-500.

LI S., CHEN Q., LI H., WU Y., FENG J., YAN Y. (2017). Mesenchymal circulating tumor cells (CTCs) and OCT4 mRNA expression in CTCs for prognosis prediction in patients with non-small-cell lung cancer. Clinical and Translational Oncology 19: 1147-1153. https://doi.org/10.1007/s12094-017-1652-z

MA Y.C., WANG L., YU F.L. (2013). Recent Advances and Prospects in the Isolation by Size of Epithelial Tumor Cells (ISET) Methodology. Technology in Cancer Research \& Treatment 12: 295-309. https://doi.org/10.7785/tcrt.2012.500328

MANSILLA C., SORIA E., RAMÍREZ N. (2018). The identification and isolation of CTCs: A biological Rubik's cube. Critical Reviews in Oncology/Hematology 126: 129-134. https://doi.org/10.1016/j.critrevonc.2018.03.027

MESSARITAKISI., POLITAKIE., KOTSAKIS A., DERMITZAKIE.K., KOINISF., LAGOUDAKI E., KOUTSOPOULOS A., KALLERGI G., SOUGLAKOS J., GEORGOULIAS V. (2017). Phenotypic characterization of circulating tumor cells in the peripheral blood of patients with small cell lung cancer. PLOS ONE 12: e0181211. https:// doi.org/10.1371/journal.pone.0181211

MITRA A., MISHRA L., LI S. (2015). EMT, CTCs and CSCs in tumor relapse and drugresistance. Oncotarget 6: 10697-10711. https://doi.org/10.18632/oncotarget.4037

PANTAZAKA E., VARDAS V., ROUMELIOTOU A., KAKAVOGIANNIS S., KALLERGI G. (2021). Clinical Relevance of Mesenchymal-and Stem-Associated Phenotypes in Circulating Tumor Cells Isolated from Lung Cancer Patients. Cancers 13: 2158. https://doi.org/10.3390/cancers13092158

PAPADAKIM. A., KALLERGI G., ZAFEIRIOUZ., MANOURASL., THEODOROPOULOS P. A., MAVROUDIS D., GEORGOULIAS V., AGELAKI S. (2014). Co-expression of putative stemness and epithelial-to-mesenchymal transition markers on single circulating tumour cells from patients with early and metastatic breast cancer. BMC Cancer 14: 651. https://doi.org/10.1186/1471-2407-14-651
RAIMONDI C., GRADILONE A., NASO G., VINCENZI B., PETRACCA A., NICOLAZZO C., PALAZZO A., SALTARELLI R., SPREMBERG F., CORTESI E., GAZZANIGA P. (2011). Epithelial-mesenchymal transition and stemness features in circulating tumor cells from breast cancer patients. Breast Cancer Research and Treatment 130: 449-455. https://doi.org/10.1007/s10549-011-1373-X

RAN J., YANG H.H., HUANG H.P., HUANG H.L., XU Z., ZHANG W., WANG Z.X. (2020). ZEB1 modulates endometrial receptivity through epithelial-mesenchymal transition in endometrial epithelial cells in vitro. Biochemical and Biophysical Research Communications 525: 699-705. https://doi.org/10.1016/j.bbrc.2020.02.153

RIETHDORF S., FRITSCHE H., MÜLLER V., RAUT., SCHINDLBECKC., RACKB., JANNI W., COITH C., BECK K., JÄNICKE F., JACKSON S., GORNET T., CRISTOFANILLI M., PANTEL K. (2007). Detection of Circulating Tumor Cells in Peripheral Blood of Patients with Metastatic Breast Cancer: A Validation Study of the CellSearch System. Clinical Cancer Research 13: 920-928. https://doi.org/10.1158/10780432.CCR-06-1695

SATELLI A., BATTH I., BROWNLEE Z., MITRA A., ZHOU S., NOH H., ROJAS C. R., LI H., MENG Q. H., LI S. (2017). EMT circulating tumor cells detected by cell-surface vimentin are associated with prostate cancer progression. Oncotarget 8: 4932949337. https://doi.org/10.18632/oncotarget.17632

SERRANO M. J., ORTEGA F. G., ALVAREZ-CUBERO M. J., NADAL R., SANCHEZ-ROVIRAP., SALIDO M., RODRÍGUEZM., GARCÍA-PUCHE J. L., DELGADO-RODRIGUEZ M., SOLÉ F., GARCÍA M. A., PERÁN M., ROSELL R., MARCHAL J. A., LORENTE J. A. (2014). EMT and EGFR in CTCs cytokeratin negative non-metastatic breast cancer. Oncotarget 5: 7486-7497. https://doi.org/10.18632/oncotarget.2217

SHIOIRI M., SHIDA T., KODA K., ODA K., SEIKE K., NISHIMURA M., TAKANO S., MIYAZAKI M. (2006). Slug expression is an independent prognostic parameter for poor survival in colorectal carcinoma patients. British Journal of Cancer 94: 1816-1822. https://doi.org/10.1038/sj.bjc.6603193

SIRAVEGNA G., MARSONI S., SIENA S., BARDELLI A. (2017). Integrating liquid biopsies into the management of cancer. Nature Reviews Clinical Oncology 14: 531-548. https://doi.org/10.1038/nrclinonc.2017.14

SWENNENHUIS J.F., VAN DALUM G., ZEUNE L.L., TERSTAPPEN L.W.M.M. (2016). Improving the CellSearch ${ }^{\circledR}$ system. Expert Review of Molecular Diagnostics 16: 1291-1305. https://doi.org/10.1080/14737159.2016.1255144

TAM W. L., WEINBERG R. A. (2013). The epigenetics of epithelial-mesenchymal plasticity in cancer. Nature Medicine 19: 1438-1449. https://doi.org/10.1038/nm.3336

TAMMINGA M., ANDREE K. C., HILTERMANN T. J. N., JAYAT M., SCHUURING E., VAN DEN BOS H., SPIERINGS D. C. J., LANSDORP P. M., TIMENS W., TERSTAPPEN L. W. M. M., GROEN H. J. M. (2020). Detection of Circulating Tumor Cells in the Diagnostic Leukapheresis Product of Non-Small-Cell Lung Cancer Patients Comparing CellSearch ${ }^{\circledR}$ and ISET. Cancers 12: 896. https://doi.org/10.3390/ cancers12040896

THEODOROPOULOSP. A., POLIOUDAKIH., AGELAKIS., KALLERGI G., SARIDAKIZ., MAVROUDIS D., GEORGOULIAS V. (2010). Circulating tumor cells with a putative stem cell phenotype in peripheral blood of patients with breast cancer. Cancer Letters 288: 99-106. https://doi.org/10.1016/j.canlet.2009.06.027

YANG K. R., MOONEY S. M., ZARIF J. C., COFFEY D. S., TAICHMAN R. S., PIENTA K. J. (2014). Niche Inheritance: A Cooperative Pathway to Enhance Cancer Cell Fitness Through Ecosystem Engineering. Journal of Cellular Biochemistry 115: 1478-1485. https://doi.org/10.1002/jcb.24813 